\title{
Cultivo in vitro de embriões zigóticos e aclimatação de plântulas de coqueiro-anão
}

\author{
Ana da Silva Lédo(1), Kicia Karinne Pereira Gomes ${ }^{(1)}$, Sarah Brandão Santa Cruz Barboza(1),

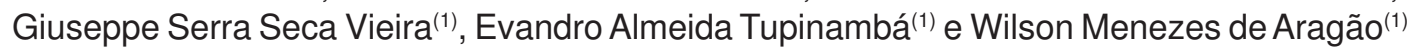

\begin{abstract}
(1)Embrapa Tabuleiros Costeiros, Av. Beira Mar, no 3.250, CEP 49025-040 Aracaju, SE. E-mail: analedo@cpatc.embrapa.br, kiciagomes@yahoo.com.br, giuseppe@cpatc.embrapa.br, sarah@cpatc.embrapa.br, tupi@cpatc.embrapa.br, aragaowm@cpatc.embrapa.br

Resumo - O objetivo deste trabalho foi ajustar os protocolos de cultivo in vitro de embriões zigóticos e de aclimatação de plântulas de coqueiro-anão-verde do Brasil de Jiqui (Cocos nucifera L.). Os embriões zigóticos maduros, colocados assepticamente em meio de cultura líquido Y3 suplementado com 27,8 mg L-1 de Fe $\mathrm{SO}_{4} .7 \mathrm{H}_{2} \mathrm{O}$ e $60 \mathrm{~g} \mathrm{~L}^{-1}$ de sacarose, apresentaram maior germinação e formação de plântulas normais. As plântulas transferidas para meio indutor de enraizamento Y3, gelificado e suplementado com $1 \mathrm{mg} \mathrm{L}^{-1}$ de ANA, 0,5 mg L-1 de BAP e 2,5 $\mathrm{g} \mathrm{L}^{-1}$ de carvão ativado, apresentaram incremento do desenvolvimento radicular e da parte aérea. Na fase de aclimatação, o substrato composto por areia lavada e pó de casca de coco seco, na proporção de 1:1, proporcionou maior sobrevivência das plântulas $(58,33 \%)$, maior crescimento da parte aérea $(39,08 \mathrm{~cm})$ e maior número de folhas $(6,33)$. Os protocolos estabelecidos para o cultivo in vitro de embriões zigóticos e a aclimatação de coqueiro-anão-verde de Jiqui podem ser utilizados no intercâmbio e conservação de germoplasma.
\end{abstract}

Termos para indexação: Cocos nucifera, germinação in vitro, meios de cultura, regulador de crescimento.

\section{In vitro culture of zygotic embryos and acclimatization of green dwarf coconut palm}

\begin{abstract}
The objective of this work was to improve the protocols for culture and acclimatization of green dwarf coconut palm (Cocos nucifera L.). Mature zygotic embryos, cultivated in vitro aseptically in Y3 liquid medium culture, supplemented with $27.8 \mathrm{mg} \mathrm{L}^{-1}$ of $\mathrm{Fe}_{2} \mathrm{SO}_{4} \cdot 7 \mathrm{H}_{2} \mathrm{O}$ and $60 \mathrm{~g} \mathrm{~L}^{-1}$ of sucrose, presented higher germination and normal plantlets formation. The plantlets transferred to $\mathrm{Y} 3$ semi-solid medium culture supplemented with $1 \mathrm{mg} \mathrm{L}^{-1}$ of ANA, $0.5 \mathrm{mg} \mathrm{L}^{-1}$ of BAP and $2.5 \mathrm{~g} \mathrm{~L}^{-1}$ of activated charcoal, promoted better root and shoot development. In the acclimatization phase, the 1:1 substrate composed of washed sand and coconut coir dust provided higher survival of plantlets $(58.33 \%)$, larger growth of the aerial part $(39.08 \mathrm{~cm})$ and larger number of leaves (6.33). The established protocols for in vitro culture of zygotic embryos and acclimatization of green dwarf coconut palm plantlets can be applied to germplasm exchange and conservation.
\end{abstract}

Index terms: Cocos nucifera, in vitro germination culture media, growth regulator.

\section{Introdução}

A cultura de embriões tem sido utilizada para coleta e intercâmbio de germoplasma de coqueiro, porque suas sementes apresentam grandes dimensões, o que aumenta drasticamente o volume de material a ser coletado e conservado (Engelmann \& Batugal, 2002). Técnicas in vitro simples e eficientes têm sido estabelecidas por vários grupos de pesquisa em diversos países. A cultura de embriões zigóticos também tem sido aplicada na conservação de germoplasma a médio e a longo prazo (Assy-Bah \& Engelmann, 1992, 1993). Entretanto, a aplicação dessas técnicas requer o estabelecimento de protocolos eficientes de germinação e desenvolvimento in vitro de embriões e aclimatação em condições in vivo, para o desenvolvimento de plantas adaptadas às condições de campo.

O primeiro protocolo de cultura de embriões de coqueiro foi publicado por De Guzman \& Del Rosario (1964) para o coqueiro Makapuno, e outros foram estabelecidos posteriormente (Assy-Bah et al., 1987; Rillo \& Paloma, 1992; Ashburner et al., 1995). Resultados promissores com coqueiro-gigante e coqueiro-anão têm sido alcançados no Brasil (Siqueira et al., 1998; Silva, 2002; Angelo et al., 2003; Santana \& Teixeira, 2004). Entretanto, tem-se observado alta 
variabilidade no desempenho do cultivo in vitro de embriões de coqueiro, dentro e entre ecótipos (Angelo et al., 2003), embora ainda não esteja esclarecido quanto dessa variabilidade é genética ou ambiental.

Alguns fatores no cultivo de embriões de coqueiro necessitam de mais estudos, a fim de se obter a formação de um sistema radicular funcional in vitro, que permita maior sobrevivência das plantas na fase de aclimatação. Os carboidratos desempenham papel importante na manutenção de uma osmolaridade adequada do meio de cultura e promoção do crescimento embrionário (Hu \& Ferreira, 1998). O aumento, a redução ou a eliminação da sacarose no meio de cultivo podem ser determinantes no sucesso do enraizamento in vitro para muitas plantas (Calamar \& Klerk, 2002). O ferro, considerado elemento essencial nas transformações energéticas, ocorre em proteínas do grupo heme e não-heme, está diretamente implicado no metabolismo de ácidos nucléicos, atua como ativador enzimático e pode influenciar o desenvolvimento in vitro e promover oxidação dos explantes (Caldas et al., 1998; Dechen et al. citados por Utino et al., 2001). Diferentes concentrações de $\mathrm{Fe}_{2} \mathrm{SO}_{4} \cdot 7 \mathrm{H}_{2} \mathrm{O}$ têm sido utilizadas em meios nutritivos $\mathrm{Y} 3$ e MS, para o cultivo in vitro de embriões zigóticos de variedades de coqueiroanão e coqueiro-gigante, com variação nas respostas morfogenéticas (Engelmann \& Batugal, 2002).

A aclimatação de plântulas tem sido um grande entrave na micropropagação de muitas espécies, principalmente de palmeiras. A transferência de ambiente protegido, estéril, com açúcares e com umidade saturada, para ambiente não-estéril, sem açúcares e com reduzida umidade, tem levado à perda de plantas, baixa taxa de crescimento e período prolongado na obtenção de plantas completamente aclimatadas (Souza Júnior et al., 2001). A transferência de plântulas produzidas sob condições controladas, para um ambiente sob condições naturais, deve ser progressiva evitando estresses (Silva et al., 1995).

A maioria dos protocolos publicados, sobre o cultivo in vitro de embriões de coqueiro, cita a areia esterilizada como substrato na fase de aclimatação, e os resultados obtidos indicam baixa porcentagem de sobrevivência das plantas (Engelmann \& Batugal, 2002). Pesquisas têm sido conduzidas com o objetivo de aumentar a taxa de sobrevivência. O cultivo in vitro de coqueiro-anão amarelo da Malásia, em condições de casa de vegetação sob luz natural, promoveu um efeito positivo na taxa de sobrevivência, quando as plântulas foram transferidas para condições ex vitro em substrato composto por areia, argila e musgo (Talavera et al., 2005).

O substrato, por meio de suas características químicas, físicas e biológicas, exerce grande influência na adaptação e desenvolvimento inicial das plantas em condições naturais. O uso de pó de casca de coco verde ou maduro, na composição de substratos, tem sido promissor para a produção de mudas de diferentes espécies (Correia et al., 2003; Terceiro Neto et al., 2004). Além da facilidade de produção, baixo custo e alta disponibilidade, é uma alternativa de uso adequado para os resíduos agroindustriais de coco (Carrijo et al., 2002).

O objetivo deste trabalho foi ajustar protocolos de cultivo in vitro de embriões zigóticos e de aclimatação de plântulas de coqueiro-anão-verde do Brasil de Jiqui em condições de telado.

\section{Material e Métodos}

As atividades foram realizadas no Laboratório de Cultura de Tecidos de Plantas, da Embrapa Tabuleiros Costeiros. Foram utilizados embriões zigóticos de frutos maduros, com 11 a 12 meses após a fertilização, de coqueiro-anão-verde do Brasil de Jiqui, proveniente do Banco Ativo de Germoplasma de Coco, da Embrapa Tabuleiros Costeiros, no Campo Experimental do Betume, em Neópolis, SE.

Cilindros de endosperma, com embriões extraídos de frutos maduros, foram submetidos à pré-assepsia com imersão em $\mathrm{NaClO}$ comercial e lavados em água potável, por três vezes, no local da coleta (Figura $1 \mathrm{~A}$ ).

Em condições assépticas, os embriões foram excisados das seções de endosperma (Figura 1 B), imersos em álcool etílico a 70\%, por dois minutos e, em seguida, em solução de $\mathrm{NaClO}$ comercial por 20 minutos, sob agitação e, posteriormente, foram lavados quatro vezes em água destilada e autoclavada. Os embriões zigóticos foram colocados em tubos de ensaio com $10 \mathrm{~mL}$ de meio de cultura Y3 líquido (Eeuwens, 1976), sem carvão ativado (Figura $1 \mathrm{C}$ ). $\mathrm{O}$ pH do meio de cultura foi previamente ajustado para $5,8 \mathrm{e}$, em seguida, submetido à esterilização em autoclave a $121^{\circ} \mathrm{C}$, sob pressão de $1,05 \mathrm{~kg} \mathrm{~cm}^{-2}$, durante 15 minutos.

$\mathrm{O}$ experimento foi instalado em delineamento inteiramente casualizado, em esquema fatorial $2 \times 3$ (duas concentrações de sacarose $\mathrm{x}$ três concentrações de $\mathrm{Fe}_{2} \mathrm{SO}_{4} \cdot 7 \mathrm{H}_{2} \mathrm{O}$ ), com cinco repetições. As seguintes combinações foram testadas: S1F1 (sacarose $60 \mathrm{~g} \mathrm{~L}^{-1}$ $+\mathrm{Fe}_{2} \mathrm{SO}_{4} \cdot 7 \mathrm{H}_{2} \mathrm{O} 13,9 \mathrm{mg} \mathrm{L}^{-1}$ ); S1F2 (sacarose $60 \mathrm{~g} \mathrm{~L}^{-1}$ 


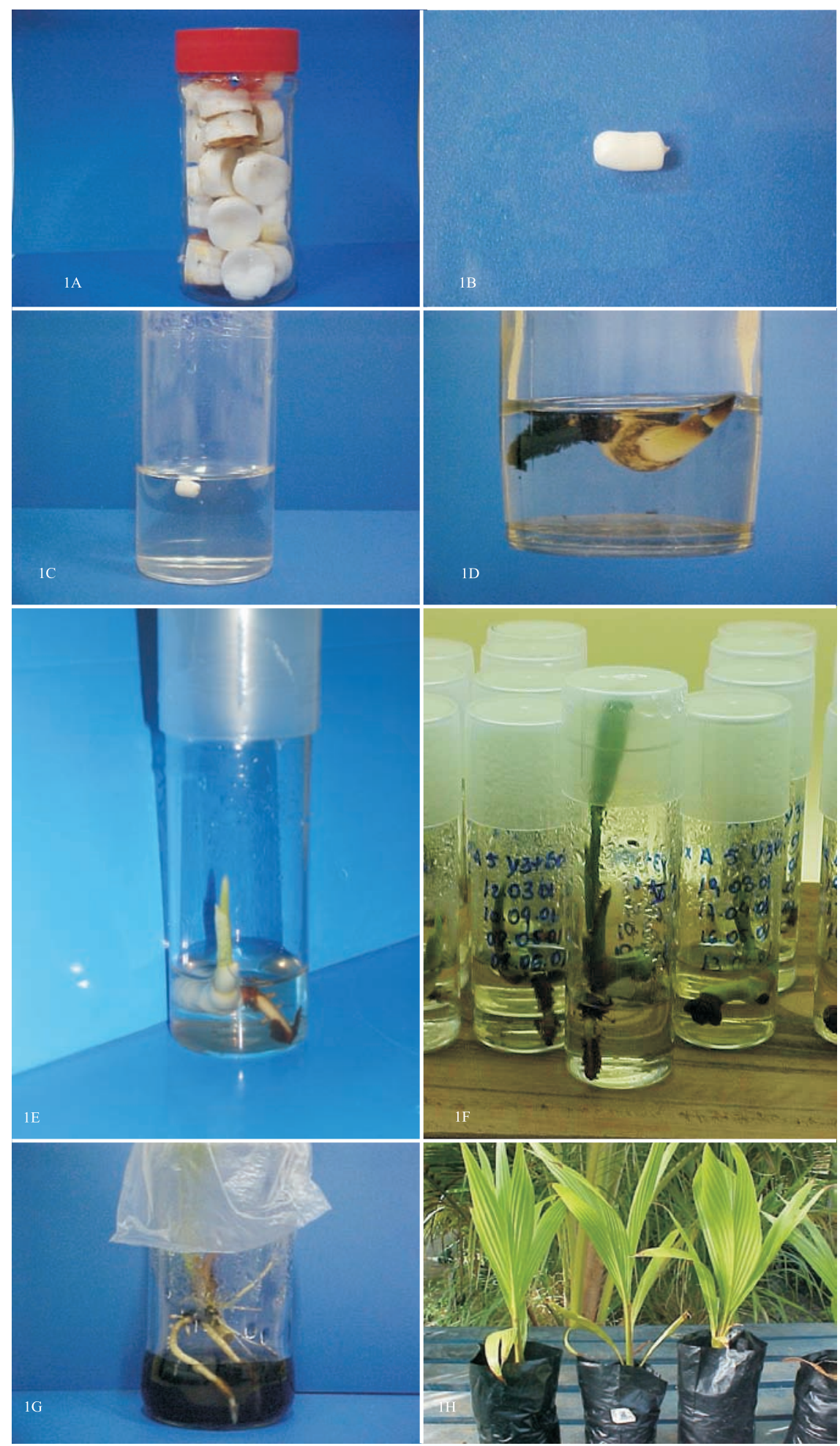

Figura 1. Esquema do cultivo de embriões zigóticos de coqueiro-anão-verde do Brasil de Jiqui. A) discos de endosperma; B) embrião zigótico excisado do disco de endosperma; C) embrião zigótico introduzido em meio de cultura Y3 líquido; D) emissão da plúmula e da raiz; E) plântulas desenvolvidas aos 70 dias; F) plântulas desenvolvidas aos 150 dias; G) plântulas transferidas para meio de cultura Y3 gelificado, para indução de enraizamento; H) mudas em fase de aclimatação, aos 120 dias de cultivo sob telado. 
$+\mathrm{Fe}_{2} \mathrm{SO}_{4} .7 \mathrm{H}_{2} \mathrm{O} 27,8 \mathrm{mg} \mathrm{L}^{-1}$ ); S1F3 (sacarose $60 \mathrm{~g} \mathrm{~L}^{-1}$ $+\mathrm{Fe}_{2} \mathrm{SO}_{4} .7 \mathrm{H}_{2} \mathrm{O} 41,7 \mathrm{mg} \mathrm{L}^{-1}$ ); S2F1 (sacarose $80 \mathrm{~g} \mathrm{~L}^{-1}$ $+\mathrm{Fe}_{2} \mathrm{SO}_{4} .7 \mathrm{H}_{2} \mathrm{O} 13,9 \mathrm{mg} \mathrm{L}^{-1}$ ); S2F2 (sacarose $80 \mathrm{~g} \mathrm{~L}^{-1}$ $+\mathrm{Fe}_{2} \mathrm{SO}_{4} \cdot 7 \mathrm{H}_{2} \mathrm{O} 27,8 \mathrm{mg} \mathrm{L}^{-1}$ ); $\mathrm{S} 2 \mathrm{~F} 3$ (sacarose $80 \mathrm{~g} \mathrm{~L}^{-1}$ $\left.+\mathrm{Fe}_{2} \mathrm{SO}_{4} \cdot 7 \mathrm{H}_{2} \mathrm{O} 41,7 \mathrm{mg} \mathrm{L}^{-1}\right)$.

As culturas foram mantidas em sala de crescimento à temperatura de $26 \pm 2^{\circ} \mathrm{C}$, umidade relativa do ar em torno de $70 \%$, e ausência de luz até a emissão da plúmula e da raiz (Figura $1 \mathrm{D}$ ); em seguida, foram colocadas em condições de fotoperíodo de 12 horas de luz branca fria, sob $52 \mu \mathrm{mol} \mathrm{m}{ }^{-2} \mathrm{~s}^{-1}$ de irradiância e 12 horas de escuro. A renovação do meio de cultura ocorreu em intervalos de 30 a 35 dias.

Aos 70 dias após a introdução em meio de cultura, foram avaliadas a porcentagem de germinação dos embriões zigóticos (GER), porcentagem de plântulas normais $(\mathrm{PN})$ e comprimento da parte aérea (CPA) e da raiz primária $(\mathrm{CR})$ (Figura $1 \mathrm{E}$ ). Como plântulas anormais, foram consideradas aquelas que apresentavam crescimento atrofiado da parte aérea ou do sistema radicular ou do haustório.

Aos 150 dias de cultivo in vitro (Figura $1 \mathrm{~F}$ ), as plântulas foram transferidas para o meio indutor de enraizamento gelificado com Phytagel $2 \mathrm{~g} \mathrm{~L}^{-1}$, composto pelos sais e vitaminas do meio $\mathrm{Y} 3$, suplementado com ácido naftalenoacético (ANA) $1 \mathrm{mg} \mathrm{L}^{-1}$, 6-benzilaminopurina (BAP) $0,5 \mathrm{mg} \mathrm{L}^{-1}$, carvão ativado $2,5 \mathrm{~g} \mathrm{~L}^{-1}$ e sacarose $40 \mathrm{~g} \mathrm{~L}^{-1}$ (Figura $1 \mathrm{G}$ ). As plântulas foram mantidas nas mesmas condições da etapa anterior, com a renovação do meio de cultura de igual composição, em intervalos de 30 a 35 dias. Aos 60 dias após a transferência, foi avaliado o número médio, por plântula, de raízes primárias, raízes secundárias e folhas. Como raiz primária foi considerada a raiz oriunda do pólo radicular e, como secundárias, as raízes formadas a partir do periciclo da raiz primária.

Aos 210 dias de cultivo in vitro, as plântulas tiveram seu sistema radicular cuidadosamente lavado com água destilada e mergulhado, por 5 minutos, em solução de fungicida (Benomil $2 \mathrm{~g} \mathrm{~L}^{-1}$ ). Em seguida, foram transplantadas em sacos de polietileno preto perfurados, nas dimensões $28 \times 20 \mathrm{~cm}$, com os seguintes substratos areia lavada (AL) e mistura de areia lavada e pó de casca de coco seco (ALPC), na proporção de 1:1, em volume. Os dois substratos foram esterilizados em autoclave a $121^{\circ} \mathrm{C}$, sob pressão de $1,05 \mathrm{~kg} \mathrm{~cm}^{-2}$, durante 15 minutos.

Para avaliação da aclimatação, utilizou-se o delineamento inteiramente casualizado, com dois tratamentos e quinze repetições, e cada unidade experimental foi constituída de três mudas. As mudas foram mantidas sob telado com $50 \%$ de sombreamento (Figura $1 \mathrm{H}$ ), e foram cobertas, nos primeiros sete dias, com sacos de plástico transparente, submetidas regularmente à irrigação e, de dois em dois dias, suplementadas com solução nutritiva PCA-ARC (Engelmann \& Batugal, 2002). Sessenta dias após o transplantio, foi avaliada a porcentagem de sobrevivência das mudas e, aos 30 e 120 dias, foram avaliados o número de folhas vivas e a altura da parte aérea $(\mathrm{cm})$. A altura da parte aérea foi mensurada a partir do nível do substrato até a extremidade da maior folha.

As médias das variáveis mensuradas nos experimentos foram submetidas à análise de variância pelo teste $\mathrm{F} \mathrm{e}$, quando significativas, foram comparadas pelo teste de Tukey, a 5\% de probabilidade.

\section{Resultados e Discussão}

Não houve interação entre as concentrações de sacarose e $\mathrm{Fe}_{2} \mathrm{SO}_{4} .7 \mathrm{H}_{2} \mathrm{O}$ para todas as variáveis analisadas. Houve diferença significativa entre as concentrações de sacarose, para a porcentagem de plântulas normais e comprimento da parte aérea aos 70 dias, e de $\mathrm{Fe}_{2} \mathrm{SO}_{4} .7 \mathrm{H}_{2} \mathrm{O}$ para porcentagem de germinação de embriões zigóticos aos 30 dias de introdução em meio de cultura.

A concentração de $60 \mathrm{~g} \mathrm{~L}^{-1}$ de sacarose promoveu a formação de $83,33 \%$ de plântulas normais e o maior desenvolvimento de parte aérea $(1,27 \mathrm{~cm})$ (Tabela 1). Resultados semelhantes foram obtidos por Assy-Bah et al. (1989), que obtiveram maior porcentagem de germinação e melhor desenvolvimento in vitro de embriões de C. nucifera (híbrido PB 121), em meio MS com $60 \mathrm{~g} \mathrm{~L}^{-1}$ de sacarose; no entanto, observaram efeito inibitório do aumento da concentração de sacarose para $120 \mathrm{~g} \mathrm{~L}^{-1}$ na porcentagem de germinação. Silva (2002) também obteve melhor desenvolvimento de embriões nos meios de cultivo MS e Y3, suplementados com $60 \mathrm{~g} \mathrm{~L}^{-1}$ de sacarose.

Considerando-se que a elevada pressão osmótica reduz o crescimento das plantas e afeta o metabolismo celular (Caldas et al., 1998), o aumento da concentração de sacarose de $60 \mathrm{~g} \mathrm{~L}^{-1}$ para $80 \mathrm{~g} \mathrm{~L}^{-1}$, no meio de cultura, provavelmente promoveu um efeito depressivo no metabolismo das plântulas, o que resultou em maior porcentagem de plântulas anormais. Altas concentrações de sacarose no meio de cultura também afetam a capacidade da enzima Rubisco o que induz ao decréscimo 
na fotossíntese (Triques et al., 1997). O estabelecimento do metabolismo fotossintético, durante o desenvolvimento de plântulas de coqueiro in vitro, e algumas similaridades entre estas plântulas e plantas adultas, como por exemplo, a presença de cloroplastos ativos, foram observados por Verdeil et al. (1998).

Em meio de cultura com $13,9 \mathrm{mg} \mathrm{L}^{-1}$ e $27,8 \mathrm{mg} \mathrm{L}^{-1}$ de $\mathrm{Fe}_{2} \mathrm{SO}_{4} \cdot 7 \mathrm{H}_{2} \mathrm{O}$, todos os embriões zigóticos germinaram, com a formação de 40 e $70 \%$ de plântulas normais, respectivamente, e estes tratamentos foram estatisticamente superiores àquele com concentração de $41,7 \mathrm{mg} \mathrm{L}^{-1}$ (Tabela 1). A redução em $50 \%$ na germinação pode ser atribuída à maior oxidação dos embriões, em consequiência da concentração de ferro mais elevada. Em trabalhos com bananeira-prata, Utino et al. (2001) observaram um efeito linear do ferro sobre o grau de oxidação dos explantes. A maior absorção de ferro pelo explante pode induzir à maior produção de enzimas peroxidase e catalase, que apresentam ferro no grupo prostético (Pasqual et al., 1997) e aumentam a sua atividade após a liberação no meio de cultura o que promove o aumento da oxidação.

Embora não tenha sido detectada diferença significativa entre os valores de comprimento da parte aérea e raiz, nas concentrações de $\mathrm{Fe}_{2} \mathrm{SO}_{4} .7 \mathrm{H}_{2} \mathrm{O}$ estudadas, o aumento da concentração de $13,9 \mathrm{mg} \mathrm{L}^{-1}$ para $27,8 \mathrm{mg} \mathrm{L}^{-1}$ incrementou em mais de $45 \%$ o comprimento da raiz, tendo-se observado comportamento inverso em relação ao desenvolvimento da parte aérea (Tabela 1). As plântulas cultivadas em meio com $41,7 \mathrm{mg} \mathrm{L}^{-1}$ de $\mathrm{Fe}_{2} \mathrm{SO}_{4} .7 \mathrm{H}_{2} \mathrm{O}$ apresentaram valores inferiores em todas as variáveis avaliadas. Durante a rizogênese, o crescimento acelerado das raízes pode retardar o desenvolvimento da parte aérea, porque o

Tabela 1. Porcentagem de germinação (GER) aos 30 dias, porcentagem de plântulas normais (PN), comprimento da parte aérea (CPA) e da raiz (CR), aos 70 dias após a introdução de embriões zigóticos de coqueiro-anão-verde do Brasil de Jiqui in vitro, em conseqüência de diferentes concentrações de sacarose e $\mathrm{Fe}_{2} \mathrm{SO}_{4} \cdot 7 \mathrm{H}_{2} \mathrm{O}^{(1)}$.

\begin{tabular}{ccccc}
\hline Sacarose $\left(\mathrm{mg} \mathrm{L}^{-1}\right)$ & GER & PN & CPA $(\mathrm{cm})$ & CR $(\mathrm{cm})$ \\
\hline 60 & $90,00 \mathrm{a}$ & $83,33 \mathrm{a}$ & $1,272 \mathrm{a}$ & $0,670 \mathrm{a}$ \\
80 & $76,67 \mathrm{a}$ & $33,33 \mathrm{~b}$ & $0,637 \mathrm{~b}$ & $0,946 \mathrm{a}$ \\
\hline $\mathrm{Fe}_{2} \mathrm{SO}_{4} \cdot 7 \mathrm{H}_{2} \mathrm{O}\left(\mathrm{mg} \mathrm{L}^{-1}\right)$ & GER & PN & CPA $(\mathrm{cm})$ & CR $(\mathrm{cm})$ \\
\hline 13,9 & $100,00 \mathrm{~A}$ & $40,00 \mathrm{~A}$ & $1,305 \mathrm{~A}$ & $0,840 \mathrm{~A}$ \\
27,8 & $100,00 \mathrm{~A}$ & $70,00 \mathrm{~A}$ & $0,828 \mathrm{~A}$ & $1,560 \mathrm{~A}$ \\
41,7 & $50,00 \mathrm{~B}$ & $65,00 \mathrm{~A}$ & $0,730 \mathrm{~A}$ & $0,440 \mathrm{~A}$ \\
\hline
\end{tabular}

(1)Médias na coluna seguidas por letras iguais, minúsculas ou maiúsculas, não diferem entre si pelo teste de Tukey, a 5\% de probabilidade. crescimento ativo do sistema radicular necessita de substâncias orgânicas translocadas da parte aérea para a base, o que compromete, o desenvolvimento do caule e das folhas (Barceló et al., 2001). Estes resultados indicam maior influência do ferro na rizogênese, na fase de estabelecimento in vitro.

Após a transferência das plântulas para o meio enraizador Y3 gelificado, suplementado com reguladores de crescimento e carvão ativado, observou-se um aumento no desenvolvimento radicular e da parte aérea, aos 60 dias após a transferência. O número médio de raízes primárias, de raízes secundárias por plântula e o comprimento médio da raiz principal foram de 1,83, 11,89 e 4,9 cm, respectivamente. O número médio de folhas e o comprimento médio da parte aérea foi de 2,26 e $13,34 \mathrm{~cm}$, respectivamente. O carvão ativado, por adsorver substâncias inibitórias do meio ou produtos tóxicos liberados pelos explantes, promove o crescimento de embriões (Ribeiro et al., 2000). De acordo com Grattapaglia \& Machado (1998), o carvão ativado em concentrações de 0,1 a $2 \%$ pode ser benéfico em alguns casos. Fisicamente, ele simula a condição de escuro, no qual as raízes normalmente se desenvolvem melhor, pela redução da incidência de luz na zona de crescimento ativo do sistema radicular.

$\mathrm{Na}$ fase de aclimatação, houve diferença significativa entre os substratos avaliados, quanto à porcentagem de sobrevivência aos 60 dias, e quanto à altura da parte aérea e número de folhas aos 120 dias, após a transferência das plântulas para condições de telado (Tabela 2). A areia lavada combinada com pó de casca de coco seco proporcionou maior sobrevivência $(58,33 \%)$ de plântulas regeneradas em condições de telado, quando comparada à areia lavada (23\%). Estes resultados foram bem superiores aos obtidos por Samosir et al. (1998), que alcançaram apenas $30 \%$ de

Tabela 2. Porcentagem de sobrevivência (SOB), aos 60 dias, e número de folhas (NFOL) e comprimento da parte aérea (CPA) aos 30 e 120 dias, de plântulas de coqueiro-anão-verde do Brasil de Jiqui regeneradas in vitro, após a transferência para substratos constituídos de areia lavada (AL) e areia lavada e pó de casca de coco seco (ALPC), sob telado(1).

\begin{tabular}{|c|c|c|c|c|c|}
\hline \multirow[t]{2}{*}{ Substrato } & \multicolumn{2}{|c|}{30 dias } & \multicolumn{2}{|c|}{120 dias } & \multirow{2}{*}{$\begin{array}{c}60 \text { dias } \\
\text { SOB }\end{array}$} \\
\hline & NFOL & $\mathrm{CPA}(\mathrm{cm})$ & NFOL & CPA $(\mathrm{cm})$ & \\
\hline$\overline{\mathrm{AL}}$ & $2,38 \mathrm{a}$ & $15,38 \mathrm{a}$ & $5,55 b$ & $36,00 \mathrm{~b}$ & $23,00 \mathrm{~b}$ \\
\hline $\operatorname{ALPC}(1: 1)$ & $2,50 \mathrm{a}$ & $16,52 \mathrm{a}$ & $6,33 a$ & $39,08 \mathrm{a}$ & $58,33 \mathrm{a}$ \\
\hline
\end{tabular}

${ }^{(1)}$ Médias na coluna seguidas por letras iguais não diferem entre si pelo teste de Tukey, a 5\% de probabilidade. 
sobrevivência de plântulas de coqueiro regeneradas in vitro. Em estudo comparativo de três protocolos de cultura de embriões de coqueiro, Capote et al. (2002) observaram baixa sobrevivência de plântulas em areia esterilizada que foi de 5,25 a $31,4 \%$.

O desenvolvimento da parte aérea, nos 30 primeiros dias de aclimatação, foi similar nos dois substratos avaliados, tendo-se observado, em média, pequeno incremento do desenvolvimento da parte aérea, quando comparado com a etapa final da fase in vitro. A transição da plântula para a condição autotrófica requer adaptações de ordem fisiológica e morfológica que possam retardar a retomada do desenvolvimento celular.

A adição de pó de casca de coco seco à areia lavada, na proporção de 1:1 em volume, induziu as plantas a maior crescimento da parte aérea e maior número de folhas aos 120 dias (Tabela 2). O pó da casca de coco seco conferiu ao substrato maior capacidade de retenção de água e, consequentemente, melhor sobrevivência e vigor das plantas. Na fase de aclimatação, o estresse hídrico das plantas é geralmente o maior problema, e a manutenção da umidade relativa alta, desde a retirada das plantas do meio de cultura até a retomada do crescimento, é um fator chave para a sua sobrevivência inicial (Grattapaglia \& Machado, 1998). Resultados semelhantes foram obtidos por Souza Júnior et al. (2001), que observaram valores médios inferiores duas variáveis de crescimento de plântulas de abacaxizeiro, aclimatadas em substrato composto por areia. Mudas de violeta africana (Saintpaulia ionantha Wendl) apresentaram bom crescimento na aclimatação ex vitro, nos substratos comerciais Plantagro e Bioplant, seguidos pelo pó de casca de coco seco e vermiculita (Terceiro Neto et al., 2004). A adição de pó da casca do coco maduro ou verde, na proporção de $20 \%$, foi eficiente na substituição de solo hidromórfico em substrato, para produção de mudas enxertadas de cajueiro-anão precoce em tubetes (Correia et al., 2003).

Neste trabalho, observou-se que em dois meses ocorreu a completa germinação dos embriões com a emissão da raiz primária, da parte aérea e a formação do haustório (Figura 2). Para incrementar a formação
Meio 1:

Meio de cultura $\mathrm{Y} 3$

$\left(\mathrm{Fe}_{2} \mathrm{SO}_{4} \cdot 7 \mathrm{H}_{2} \mathrm{O} 27,8 \mathrm{mg} \mathrm{L}^{-1}\right)$

Sacarose $60 \mathrm{~g} \mathrm{~L}^{-1}$

Escuro, $26 \pm 2^{\circ} \mathrm{C}$

Subcultivos 30-35 dias

Meio 2:

Meio de cultura Y3

Carvão ativado $2,5 \mathrm{~g} \mathrm{~L}^{-1}$

Sacarose $40 \mathrm{~g} \mathrm{~L}^{-1}$, Phytagel $2 \mathrm{~g} \mathrm{~L}^{-1}$

ANA $2 \mathrm{mg} \mathrm{L}^{-1}$, BAP $0,5 \mathrm{mg} \mathrm{L}^{-1}$

Fotoperíodo $12 / 12$ horas, $26+2^{\circ} \mathrm{C}$

Subcultivos 30-35 dias

Substrato:

Areia lavada esterilizada e pó de casca de coco seco (1:1, v:v)

Cobertura com saco de plástico

transparente até o $7^{\circ}$ dia

Irrigação com solução nutritiva

Sombreamento $50 \%$ (telado).

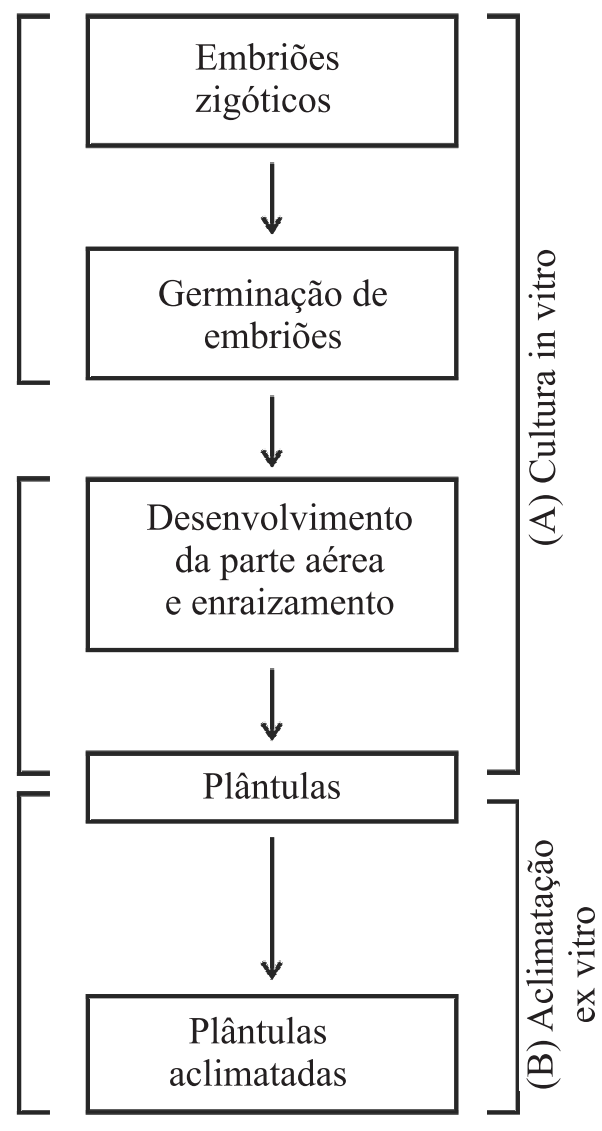

90,00

2

83,33

3

83,33

7

58,33

11

Figura 2. Protocolos: A) cultura in vitro de embriões zigóticos e formação de plântulas de coqueiro-anão-verde do Brasil de Jiqui; B) aclimatação ex vitro de plântulas sob telado. 
de um sistema radicular funcional, aos cinco meses as plântulas foram transferidas para o meio indutor em presença de carvão ativado, ANA e BAP, onde permaneceram por mais dois meses. A aclimatação foi bem sucedida em substrato composto por areia lavada e pó de casca de coco seco esterilizados, na proporção de 1:1 em volume.

\section{Conclusões}

1. A germinação de embriões zigóticos, com formação de plântulas normais de coqueiro-anão-verde do Brasil de Jiqui é eficiente em meio Y3 líquido, com 27,8 $\mathrm{mg} \mathrm{L}^{-1}$ de $\mathrm{Fe}_{2} \mathrm{SO}_{4} .7 \mathrm{H}_{2} \mathrm{O}$ e $60 \mathrm{~g} \mathrm{~L}^{-1}$ de sacarose.

2. Maior incremento no desenvolvimento do sistema radicular e parte aérea das plântulas são obtidos em meio Y3 gelificado, em presença de ANA, BAP e carvão ativado.

3. Substrato composto por areia lavada e pó de casca de coco esterilizados, na proporção de 1:1, em volume, é eficiente na aclimatação de plântulas.

4. É possível a conversão in vitro de embriões zigóticos, isolados de frutos maduros, em mudas completas e normais.

5. O protocolo estabelecido pode ser utilizado para o intercâmbio e conservação de germoplasma de coqueiroanão-verde do Brasil de Jiqui.

\section{Agradecimentos}

Ao CNPq, pelo apoio financeiro e pela concessão de bolsas; ao Banco do Nordeste do Brasil S.A. e à Fundação de Apoio à Pesquisa e à Inovação Tecnológica do Estado de Sergipe, pelo apoio financeiro.

\section{Referências}

ANGELO, P.C. da S.; LEAL, M.L.; GOMES, K.K.P. Cultivo in vitro de embriões zigóticos provenientes de variedades brasileiras de coco (Cocos nucifera L.). Ciência Rural, v.8, p.66-72, 2003.

ASHBURNER, G.R.; FAURE, M.G.; TOMLINSON, D.R.; THOMPSON, W.K. A guide to the zygotic embryo culture of coconut palms (Cocos nucifera L.). Canberra: Aciar, 1995. 16p. (ACIAR. Technical report series, 36).

ASSY-BAH, B.; DURANT-GASSELIN, T.; ENGELMANN, F.; PANNETIER, C. Culture in vitro d'embryons zygotiques de cocotier (Cocos nucifera L.). Oleagineux, v.44, p.515-523, 1989.

ASSY-BAH, B.; DURAND-GASSELIN, T.; PANNETIER, C. Use of zygotic embryo culture to collect germplasm of coconut (Cocos nucifera L.). Plant Genetic Resources Newsletter, v.71, p.4-10, 1987.
ASSY-BAH, B.; ENGELMANN, F. Cryopreservation of mature embryos of coconut (Cocos nucifera L.) and subsequent regeneration of plantlets. Cryo-Letters, v.13, p.117-126, 1992.

ASSY-BAH, B.; ENGELMANN, F. Medium-term conservation of mature embryos of coconut. Plant Cell, Tissue and Organ Culture, v.33, p.19-24, 1993.

BARCELÓ, C.J.; NICOLÁS, R.G.; SABATER, G.B.; SÁNCHEZ, T.R. Fisiología vegetal. 6.ed. Madri: Pirámide, 2001. 566p.

CALAMAR, A.; KLERK, G.J. de. Effect of sucrose on adventious root regeneration in apple. Plant Cell, Tissue and Organ Culture, v.70, p.207-212, 2002.

CALDAS, L.S.; HARIDASAN, P.; FERREIRA, M.E. Meios nutritivos. In: TORRES, A.C.; CALDAS, L.S.; BUSO, J.A. (Ed.). Cultura de tecidos e transformação genética de plantas. Brasília: Embrapa-SPI/Embrapa-CNPH, 1998. v.2. p.87-132.

CAPOTE, M.; CUETO, J.R.; ZAMORA, V.; RÍOS, A.R.; CHACÓN, $R$. Increasing the efficiency of the embryo culture technology to promote germplasm collecting in Cuba. In: ENGELMANN, F.; BATUGAL, P.A.; OLIVER, J. (Ed.). Coconut embryo in vitro culture. Malaysia: IPGRI-APO, 2002. v.2. p.138-145.

CARRIJO, O.A.; LIZ, R. de S.; MAKISHIMA, N. Fibra da casca de coco verde como substrato agrícola. Horticultura Brasileira, v.20, p.533-535, 2002.

CORREIA, D.; ROSA, M. de F.; NORÕES, E.R. de V.; ARAÚJO, F.B. de. Uso do pó da casca de coco na formulação de substratos para formação de mudas enxertadas de cajueiro-anão precoce. Revista Brasileira de Fruticultura, v.25, p.557-558, 2003.

DE GUZMAN, E.V.; DEL ROSARIO, A.G. The growth and development of Makapuno coconut in vitro. Philippine Agriculturist, v.48, p.82-94, 1964.

EEUWENS, C.J. Mineral requirements for growth and callus initiation of tissue explants excised from mature coconut palms (Cocos nucifera) and cultured in vitro. Physiologia Plantarum, v.36, p.2328, 1976.

ENGELMANN, F.; BATUGAL, P.A. Background on the development and implementation of the coconut embryo in vitro culture project. In: ENGELMANN, F.; BATUGAL, P.A.; OLIVER, J. (Ed.). Coconut embryo in vitro culture. Malaysia: IPGRI-APO, 2002. v.2. p.1-4.

GRATTAPAGLIA, D.; MACHADO, M.A. Micropropagação. In: TORRES, A.C.; CALDAS, L.S.; BUSO, J.A. (Ed.). Cultura de tecidos e transformação genética de plantas. Brasília: EmbrapaSPI/Embrapa-CNPH, 1998. v.1. p.183-260.

HU, C.Y.; FERREIRA, A.G. Cultura de embriões. In: TORRES, A.C.; CALDAS, L.S.; BUSO, J.A. (Ed.). Cultura de tecidos e transformação genética de plantas. Brasília: Embrapa-SPI/ Embrapa-CNPH, 1998. v.1. p.371-393.

PASQUAL, M.; HOFFMANN, A.; RAMOS, J.D. Cultura de tecidos vegetais: tecnologia e aplicação. Lavras: Ufla, 1997. 159p. RIBEIRO, V.G.; SANÁBIO, D.; SOUZA, C.N. de; LOPES, P.S.N.; BOCARDO, M.R.; PASQUAL, M. Efeitos de ácido giberélico e carvão ativado no cultivo in vitro de Citrus limonia Osbeck x Poncirus trifoliata (L.) Raf. Pesquisa Agropecuária Brasileira, v.35, p.27-30, 2000. 
RILLO, E.P.; PALOMA, M.B.F. In vitro culture of Makapuno coconut embryos. Coconuts Today, v.9, p.90-108, 1992.

SAMOSIR, Y.M.S.; GODWIN, I.D.; ADKINS, S.W. An improved protocol for somatic embryogenesis in coconut (Cocos nucifera L.). Acta Horticulturae, v.461, p.467-474, 1998.

SANTANA, M.C.; TEIXEIRA, S.L. Influência do ácido naftalenoacético no crescimento e enraizamento in vitro de plântulas de coqueiro (Cocos nucifera L.). Biologia Geral e Experimental, v.5, p.30-33, 2004.

SILVA, A.T. da; PASQUAL, M.; ISHIDA, J.S.; ANTUNES, L.E.C. Aclimatação de plantas provenientes da cultura in vitro. Pesquisa Agropecuária Brasileira, v.30, p.49-53, 1995.

SILVA, V. dos S. Regeneração in vitro de embriões de Cocos nucifera L. 2002. 78p. Dissertação (Mestrado) - Escola Superior de Agricultura Luiz de Queiroz, Piracicaba.

SIQUEIRA, E.R.; RIBEIRO, F.E.; ARAGÃO, W.M.; TUPINAMBÁ, E.A. Melhoramento genético do coqueiro. In: FERREIRA, J.M.S.; WARWICK, D.R.N.; SIQUEIRA, L.A. (Ed.). Cultura do coqueiro no Brasil. Aracaju: Embrapa-CPATC, 1998. p.73-95.

SOUZA JÚNIOR, E.E. de; BARBOZA, S.B.S.C.; SOUZA, L.A.C. Efeito de substratos e recipientes na aclimatação de plântulas de abacaxizeiro Ananas comosus (L.) Merril cv. pérola. Pesquisa Agropecuária Tropical, v.31, p.147-151, 2001.
TALAVERA, C.; CONTRERAS, F.; ESPADAS, F.; FUENTES, G.; SANTAMARÍA, J.M. Cultivating in vitro coconut palms (Cocos nucifera) under glasshouse conditions with natural light, improves in vitro photosynthesis nursery survival and growth. Plant Cell, Tissue and Organ Culture, v.83, p.287-292, 2005.

TERCEIRO NETO, C.P.C.; FERREYRA-HERNANDEZ, F.F.; BEZERRA, F.C.; SOUSA, R.F. de; CAVALCANTI, M.L.F. Efeito de diferentes substratos na aclimatação "ex vitro" de mudas de violeta africana (Saintpaulia ionantha Wendl). Revista de Biologia e Ciências da Terra, v.4, p.57-63, 2004.

TRIQUES, K.; RIVAL, A.; BEULE, T.; PUARD, M.; ROY, J.; NATO, A.; LAVERGNE, D.; HAVAUX, M.; VERDEIL, J.L.; SANGARE, A.; HAMON, S. Photosynthetic ability of in vitro grown coconut (Cocos nucifera $\mathrm{L}$.) plantlets derived from zygotic embryos. Plant Science, v.127, p.39-51, 1997.

UTINO, S.; CARNEIRO, I.F.; CHAVEZ, L.J. Crescimento e oxidação de explantes de bananeira-prata (Musa AAB) in vitro. I. Concentrações de sais de ferro, cobre e zinco. Revista Brasileira de Fruticultura, v.23, p.225-229, 2001.

VERDEIL, J.L.; HOCHER, V.; TRIQUES, K.; LYAKURWA, R.; RIVAL, A.; DURAND-GASSELIN, T.; ENGELMANN, F.; HAMON, S. State of research on coconut embryo culture and acclimatization techniques in the IDEFOR (Côte d'Ivoire) and ORSTOM/CIRAD laboratories (France). In: BATUGAL, P.A.; ENGELMANN, F. (Ed.). Coconut embryo in vitro culture: Malaysia: IPGRI-APO, 1997. v.1. p.1-4.

Recebido em 29 de maio de 2006 e aprovado em 20 de outubro de 2006 